\title{
Asking the Indigeneity Question of American Music Studies
}

\section{JESSICA BISSETT PEREA and GABRIEL SOLIS}

We are pleased to present this special issue of the Journal of the Society for American Music on "Music, Indigeneity, and Colonialism in the Americas." This timely collection adds a range of case studies to the discussion of Indigenous music and the history of colonial processes, while at the same time offering theoretical resources for music scholars to connect further with these threads of interdisciplinary research. While this issue only represents one step in a larger process, we see it as a meaningful part of how the Society for American Music might attempt to grapple with coloniality and engage with moves toward decolonization and decoloniality in the contemporary academy in ways that do not exacerbate current and ongoing erasures of Indigenous Peoples' presence and agency. ${ }^{1}$

In addressing myriad issues raised by keywords in our title, this volume effectively poses an "Indigeneity question" for American music historiography: what happens to American music studies if you put Indigeneity at its center? ${ }^{2}$ In addition

\footnotetext{
${ }^{1}$ This volume contributes to a series of institutional moves to decolonize music studies. Developments in sound studies include the Sounding Out! blog founded in 2009 by Jennifer Lynn Stoever, Liana M. Silva, and Aaron Trammell. See specifically Gustavus Stadler, "On Whiteness and Sound Studies," Sounding Out!, July 6, 2015, https://soundstudiesblog.com/2015/07/06/on-whiteness-and-sound-studies/. Recent developments in the American Musicological Society include Matthew D. Morrison, "(De)Constructing Musicology's Borders along the Color Line," Journal of the American Musicological Society 65, no. 3 (Fall 2012): 849-56; 2016 AMS special session on "Race, Ethnicity and the Profession"; Brownamsavenger, "\#AMSsowhite" Debates, February 18, 2016 https://brownamsavenger.livejournal.com/612.html; and Emily Dolan, "An Appropriate and Exemplary Literature': The JAMS Special Issue on Music, Race, and Ethnicity," June 5, 2018, http:// www.musicologynow.org/2018/06/an-appropriate-and-exemplary-literature.html. The theme for the Society for Ethnomusicology's 2006 Annual Meeting at the University of Hawai'i was "Decolonizing Ethnomusicology"; in 2015 SEM featured a President's Roundtable convened by then President Beverly Diamond on "Indigenous Theory in the Americas"; and the 2017 SEM preconference (convened by Victoria Lindsay Levine) "Sound Alliances: A Celebration of Indigenous Music and Culture" featured a session titled "Keywords for an Indigenized Sound Studies," convened by Jessica Bissett Perea and Trevor Reed, which has since continued as an Indigenous-led sound studies research working group. In 2016 mainstream media witnessed the rise of \#OscarsSoWhite and \#GrammysSoWhite. Yet as early as 2015, underrepresented students launched campaigns at various Western institutions along the lines of "Why is My Curriculum White?" This particular iteration by the London School of Economics was the subject of an SEM discussion listserv: https://www.youtube.com/watch? $\mathrm{v}=\mathrm{xGbxLPbetvo.} \mathrm{In} \mathrm{the} \mathrm{Society} \mathrm{for} \mathrm{American} \mathrm{Music,} \mathrm{efforts} \mathrm{include} \mathrm{Tamara} \mathrm{Levitz,}$ "Decolonizing the Society for American Music," SAM Bulletin 43, no. 3 (2017): 1-13, and this current issue of JSAM.

${ }^{2}$ To paraphrase Shari Huhndorf's 2009 reprisal of Mary Helen Washington's 1997 presidential address to the American Studies Association. See Mary Helen Washington, "Disturbing the Peace: What Happens to American Studies if you Put African American Studies at the Center?" in American Quarterly 50(1): 1-23, and Shari M. Huhndorf, "Introduction: Native American Studies and the Limits of Nationalism" in Mapping the Americas: The Transnational Politics of Contemporary Native Culture (Ithaca, NY: Cornell University Press, 2009), 3n2.
} 
to the density of Indigeneities, genres, temporalities, and geographies discussed throughout this issue, a key contribution we as editors and authors seek to make involves modeling a change in our terms and styles of engagement that advances research and writing paradigms with, by, and for (not on or about) Indigenous Peoples. ${ }^{3}$ This seemingly minor shift in prepositions radically alters a research project's orientation by centering it in an more respectful, relevant, reciprocal, and responsible space. ${ }^{4}$

We purposefully employ the concept of density, as opposed to difference or diversity, as a way to critique settler society's marginalization of Indigenous Peoples and to juxtapose-a simultaneous bringing together and keeping aparttheir inextricably intertwined realities; for without the arrival of settler societies there would be no category of "Indigenous." The term "Indigenous," while obviously still used throughout this issue, comes with various limitations. Generally speaking, Indigenous is understood as a static political category or identity, and as such engenders boundaries around who can be included or excluded from its purview. In his critique of Native American studies' epistemic fixation with cultural difference, Andersen notes the failures of differentiating Indigenous Peoples and communities solely in relation to notions of "the continuity of land, community, self-government, and culture," a move that drastically limits other conditions of possibilities for Indigenous Peoples and communities. ${ }^{5}$ In contrast, the concept of Indigeneity has been theorized by Native American and Indigenous studies scholars as both a dense, fluid, and grounded practice of identification, and an "analytic of contemporary forms of colonialism." As a dynamic and dialogic juxtaposition of Indigenous and settler realities, Indigeneity as an analytic amplifies myriad conditions of possibility for Indigenous Peoples and communities that account for dense socio-cultural realities of Indigeneity that encompass political, economic, technological, scientific, and other factors in concert with culture, community, law, and land.

To densify considerations of Indigeneity in American music historiography means to alter radically some writing conventions that are common to the Journal of the Society for American Music (and academic writing at large) by instead privileging style principles developed by Native American and Indigenous scholars

Our cautious use of the terms "Native American" and "Indigenous" is deliberate in that we are referencing imperfect English language names for a particular yet dense genre of humans known to be the original stewards of the lands and waters currently known as the Americas, the Pacific or Oceania, and the Caribbean. While this issue will use the term "Indigenous" as shorthand for the density of Native Americans, a broader question we encourage all scholars and authors to consider is whether or not the term "Indigenous" is one that your local communities would use to describe themselves.

${ }^{3}$ Sonya Atalay, Community-Based Archaeology: Research with, by, and for Indigenous and Local Communities (Berkeley: University of California Press, 2012).

${ }^{4}$ Kirkness, Verna J., and Ray Barnhardt. 2001. "First Nations and Higher Education: The Four Rs -- Respect, Relevance, Reciprocity, Responsibility.” In Knowledge Across Cultures: A Contribution to Dialogue Among Civilizations., edited by R. Hayoe and J Pan. Hong Kong: Comparative Education Research Centre, University of Hong Kong.

${ }^{5}$ See Chris Andersen, "Critical Indigenous Studies: From Difference to Density." Cultural Studies Review 15, no. 2 (2009): 88.

${ }^{6}$ See Maile Arvin, "Analytics of Indigeneity," in Native Studies Keywords, edited by Stephanie Nohelani Teves, Andrea Smith, and Michelle Raheja (Tucson: University of Arizona Press, 2015): 120. 
and authors. Opaskwayak Cree Nation scholar Gregory Younging's Elements of Indigenous Style (2018) stands as one of the most recent and comprehensive sources on the subject and details twenty-two Indigenous style principles, from which we will emphasize four as frames for this special issue. ${ }^{7}$ Though rooted in stylistic conventions, these changes ultimately point to broader changes in theory and method that we see as crucial to refiguring American music studies.

$\# 1$ "The Purpose of Indigenous Style"

"The purpose of Indigenous Style is to produce works that:

- reflect Indigenous realities as they are perceived by Indigenous Peoples.

- are truthful and insightful in their Indigenous content.

- are respectful of the cultural integrity of Indigenous Peoples."

Younging's first principle demands research and editorial work that represents Native American and Indigenous Peoples in ethical and respectful ways. We have asked the authors, and JSAM readership, to reflect early and often on two Native American and Indigenous Studies (NAIS) practices that acknowledge one's positionality, or relationality. This approach begins with increasing awareness of one's environment (lands, waters, atmospheres) through land acknowledgement-usually performed as a short statement, which recognizes the enduring relationships Indigenous Peoples have with their ancestral lands, at the beginning of public meetings, celebrations, events, and in some Canadian schools before singing the national anthem. At the time of this writing, such practices are gaining traction, particularly on lands colonized by the British empire including the United States, Australia, and New Zealand. JSAM readers may already be familiar with them, given how commonplace it has become at various activist, academic, and business gatherings. However, as many NAIS scholars rightly critique, land acknowledgements often fall short in their promise of awareness as the statements are not always followed by active engagement with or advancement of Indigenous Peoples. Following a particular land acknowledgement failure at the June 2019 Toronto Pride, Anishinaabe scholar Hayden King describes pro forma versions as tools of erasure in that they validate settler presence by "obscuring Indigenous power [and] politics." ${ }^{8}$ Instead of reminding settler and arrivant communities of their responsibilities to past, present, and future Indigenous Peoples, land acknowledgment failures become another form of what White Earth Ojibwe historian Jean O'Brien has called "firsting and lasting," a simultaneous privileging of colonial origin stories that require/necessitate

\footnotetext{
${ }^{7}$ Gregory Younging, Elements of Indigenous Style: A Guide for Writing by and about Indigenous Peoples (Edmonton, ON: Brush Education, 2018).

8 "Land Acknowledgements can be used to erase Indigenous people's presence, says writer," CBC Radio-The Current, July 2, 2019, https://www.cbc.ca/radio/thecurrent/the-current-for-july-2-20191.5196775/land-acknowledgements-can-be-used-to-erase-indigenous-people-s-presence-says-writer1.5196790 .
} 
the "last Indian" as part of a pre-history now extinct. ${ }^{9}$ Given that the majority of $J S A M$ readers and scholars live and work in the Americas, which are Indigenous lands, this practice should begin by taking stock of where you are and who are your surrounding Indigenous communities; learn the names of your local Indigenous communities; learn the Indigenous names for your local lands and waters. Whether or not you see or hear Indigenous Peoples, we assure you they are there. Part of what we want to unsettle through this issue is the expectation that Indigenous Peoples are invisible or silent.

To the long histories and ongoing legacies of misrepresentations by non-Indigenous individuals and institutions, Indigenous art worlds respond "Nothing About Us Without Us." ${ }^{10}$ Along these lines, we have asked both Indigenous and non-Indigenous authors to explicitly addresses their relationship to the Indigenous Peoples represented in their work. This common NAIS tactic refuses an invisibility of settler colonialism, and is an important tactic foregrounded in this issue. As one peer reviewer of a submission for this volume asked: "Would an Indigenous scholar leave their tribal/ethnic affiliation(s) unstated? This isn't a personal critique of the author, but a comment on how disciplinary conventions shelter settler scholars from the kind of demographic scrutiny, with its epistemological implications, that I understand Indigenous and [people of color] scholars experience routinely (I'm a white settler musicologist myself, full disclosure)." This type of disclosure does not preclude non-Indigenous scholars from writing and researching with, by, and for Indigenous peoples. We believe it is going to take a dense array of people and types of work to truly advance Indigenous Peoples' interests, and each author includes a statement of positionality or relationality as a methodological intervention and as a tactic of refusing settler invisibility.

We also note such positions and relations ourselves, as editors. Gabriel Solis is a non-Indigenous scholar, whose ancestors came to the Americas as settlers and as refugees. He works in lands of the Peoria, Kaskaskia, Peankashaw, Wea, Miami, Mascoutin, Odawa, Sauk, Mesquaki, Kickapoo, Potawatomi, Ojibwe, and Chickasaw Nations (currently occupied by the University of Illinois, Urbana-Champaign). His research relationships are primarily with Yorta Yorta, Arrernde, Guguyelandji, Woppaburra, and Torres Strait Islander people, as well as with African American, White, and Latinx performers of Black music in the US and abroad. Jessica Bissett Perea (Dena'ina) is an Indigenous scholar who is rooted (born and raised) in Dena'ina Ełnena (her ancestral homelands in southcentral Alaska), and her academic pursuits have routed her through the lands of Coast Salish and Yakama peoples (currently occupied by Edmonds Community College

\footnotetext{
${ }^{9}$ Jean M. O’Brien, Firsting and Lasting: Writing Indians out of Existence in New England (Minneapolis: University of Minnesota Press, 2010).

${ }^{10}$ The phrase "nothing about us without us" originated in disability activism of the 1990s, and more recently taken up by First Nations activists in Canada. For example, see "Kanata: Director Robert Lepage Open to Dialogue with Indigenous Artists over New Play," CBC News, July 16, 2018, https://www.cbc.ca/news/canada/montreal/quebec-robert-lepage-response-indigenous-artistscriticism-1.4748306; "Indigenous Classical Musicians Have a Message for the Music Industry: Nothing about Us without Us, CBC Radio Canada, n.d., http://www.cbc.ca/player/play/ 1450106435665 .
} 
and Central Washington University, respectively); to Numu, Newe, and Washeshu peoples (currently occupied by the University of Nevada, Reno); to Gabrielino/ Tongva peoples (currently occupied by the University of California, Los Angeles); to Chochenyo Ohlone peoples (currently occupied by the University of California, Berkeley); all of which brought her to her current position as a musicologist working in Native American Studies on Patwin land (currently occupied by the University of California, Davis) and her home on Ramaytush Ohlone land (what is currently known as San Francisco). Grounded in these roots and routes, Jessica's research centers the Indigenous aesthetics and logics of tribal and intertribal musicians with whom she works to develop methodologies and analytics that cultivate a more Native music studies, and a more musical Native American studies.

\#2 "When Indigenous style and conventional style disagree"

"Works by Indigenous authors or with Indigenous content should follow standard style references and house styles, except where these styles disagree with Indigenous styles. In these works, Indigenous style overrules other styles in cases of disagreement."

Younging's second principle manifests in this volume through a series of seemingly small yet deliberate editorial moves, including capitalizing the "I" in Indigenous and Indigeneity (which are references to our human, more-than-human, and environmental relations), and a refusal to italicize Indigenous words. ${ }^{11}$ We are thankful to Kevin Fellezs for opening with Noenoe K. Silva's (Kanaka Maoli descent) refusal to italicize Indigenous words "in keeping with the recent movement to resist making the native tongue appear foreign in writing produced in and about a native land and people."12 Likewise, we will not italicize Indigenous words unless quoting earlier works.

We also want to draw attention to the practice of acknowledging tribal affiliations (both in-text and parenthetically) directly before or after the first mention of an Indigenous person's name. Whenever possible, listed tribal affiliations should be as specific as possible, brief, and reflect the person's preferred naming practices. This form of acknowledgement advances Indigenous presence or visibility (and one could argue audibility) within academic discourse, a realm in which Indigeneity has overwhelmingly been represented by non-Indigenous persons.

Regarding naming practices, there are some key actions scholars can take, all of which begin with making informed, mindful choices about terminologies used by Indigenous Peoples themselves and to be internally consistent with said naming practices. To be sure, choosing to be consistent with one's terminologies may be an imperfect solution in some cases, as decolonizing discourse surrounding Indigenous Peoples will always be in a process of coming into being. This special

\footnotetext{
${ }^{11}$ Younging's principle thirteen - "Terms that should be capitalized"-goes into more depth on the topic of capitalization, explaining how terms relating to Indigenous, such as Indigeneity ("quality of being Indigenous"), are always capitalized (e.g., the same as Blackness, Whiteness, etc.).

${ }^{12}$ Noenoe K. Silva, "Introduction," in Aloha Betrayed: Native Hawaiian Resistance to American Colonialism (Durham, NC: Duke University Press, 2004), 13.
} 
JSAM issue aims to avoid replicating settler colonial naming practices, and the authors do so by explicitly stating and exploring the limitations and possibilities created by the deliberate and Indigenous-led naming and terminology choices they have made. To avoid using conventional terms interchangeability (from universal to particular) such as Indigenous, Native American, First Nations, American Indian, Alaska Native, Native Hawaiian, Inuit, Métis, Pueblos Indígenas, it is advisable that scholars and authors start by centering the Indigenous Peoples under consideration and privilege their ways of identification and affiliation. These identifications should start from Indigenous words for or variations on the idea of "the [real] people" (e.g., Dena'ina, Yup'ik, Ohlone, Tunxis, Wappinger, Hopi, Aymara, Kanaka Maoli, etc.). From these hyper-local and tribal-specific Indigenous identifications of personhood, one typically moves to broader categories that the Indigenous Peoples under consideration align with, such as larger language groups (e.g., Diné, Central Yupik, Nahuatl, Aymara, Quechua, Algonquin, Mohegan, Mantauk). However, knowing the difference between an Indigenous Peoples' name for themselves versus the name of a language family is an important distinction. It is from the land-based personal and linguistic identification at the center that scholars can then move outward to colonial categories of recognition, or categories that have been deemed recognizable to the settler nation state, such as those codified in colonial legislation, such as "American Indian," "Alaska Native," "Native Hawaiian" "First Nations," "Métis," "Inuit;" although not necessarily legislated, there are similar categories in Central and South America (e.g., "Pueblos Originarios" and "Pueblos Indígenas"). Lastly, it is important to note how the category of "Indigenous" is a relatively recent and global-oriented designation. For Native American people, "Indigenous" is an imperfect global category that can unwittingly perform its own kind of erasure of local and tribal specificities.

\#3 "Indigenous [Studies] and [Conventional Studies]"

"Indigenous [Studies] are their own canon and not a subgroup of [conventional studies]. Contemporary Indigenous authors' works are an extension of Traditional Knowledge systems, Indigenous histories, histories of colonization, and contemporary realities. Indigenous [Studies] frame these experiences for Indigenous readers and provide non-Indigenous readers with context for these realities. Contemporary Indigenous [Studies] connect to and extend Traditional Stories and Oral Traditions that have existed for centuries and millennia, and that long predate [conventional studies]."

To approach Younging's third principle requires a shift that stems organically out of the abovementioned positionality statement and into a commitment to privileging Native American and Indigenous knowledges and ways of music history. For example, this special issue of JSAM advocates for a more expansive view of "America" as a plural and hemispheric "Americas"-including Native American and Indigenous peoples in/from North America (the US, Canada, Greenland, and Mexico), Central America and South America, as well as the Caribbean and Pacific Islands. Since each essay considers different social, political, linguistic, and 
historical contexts, we cannot take for granted that JSAM readers will be familiar with how the settler colonial societies and/or nation states are named (or have been named over time). Thus, we have asked authors to clearly identify various layers of settler colonial societies and nation states.

This volume's goals of privileging Indigenous knowledges by interrogating the "Indigeneity question" in American music studies are twofold. First we want to expand American music studies to include a density of logics of Indigeneity, race, colonialism, gender, sexuality, nationhood, class, and so on; logics that better account for the neocolonial and neoliberal realities that affect everyone, not just Indigenous Peoples, yet are deeply rooted in the stories we tell ourselves about ourselves throughout the Americas. Regarding stories of land and liberty in a US context, O'Brien cites how the American revolution victory in 1776 is often "rendered as the 'post-colonial' moment of the nation (meaning shedding the shackles of English colonialism for the free development of a democratic republic, the United States)." ${ }^{13}$ Historian Roxanne Dunbar-Ortiz recounts numerous classroom exercises that ask students to draw maps of the United States at the time of the country's founding, following the Declaration of Independence in 1776; a majority of the students drew the entirety of the continental United States today, demonstrating the foregone conclusion and success of Manifest Destiny in our national narratives. ${ }^{14}$ American popular music histories tend to begin in the late nineteenth century, after the conclusion of the US government's westward expansion and the "close" of the frontier. In this way, some American popular music histories are disconnected from what Western Shoshone historian Ned Blackhawk calls "the violence over the land." ${ }^{15}$ Part of this Reconstruction-era nationalism involved the reification of an American sound - what some have also described as an anxiety over finding the "American" sound. Moreover, it is crucial to acknowledge the ways in which Indigenous Peoples have always already engaged music and sound as a means to resist progressive neoliberal American narratives of erasure - from Dakota folk musician Floyd Red Crow Westerman's album Custer Died for your Sins (1969) to Abenaki First Nations folk musician Mali Obomsawin's critique of Woody Guthrie's iconic song "This Land is Your Land" this past summer. ${ }^{16}$

These erasures lie at the heart of American music studies. As Loren Kajikawa explains in a recent essay, throughout the twentieth and into the twenty-first century a "possessive investment in classical music" across US-based music schools perpetuates white supremacy by fetishizing the music of white European and

\footnotetext{
${ }^{13}$ Jean M. O'Brien, "Historical Sources and Methods in Indigenous Studies: Touching on the Past, Looking to the Future," in Critical Indigenous Studies: Engagements in First World Locations, ed. Aileen Moreton-Robinson and Jean M. O’Brien (Tucson: University of Arizona Press, 2016), 15-22.

${ }^{14}$ Roxanne Dunbar-Ortiz, An Indigenous Peoples' History of the United States (Boston: Beacon Press, 2015): 2.

${ }^{15}$ Ned Blackhawk, Violence over the Land: Indians and Empires in the Early American West (Cambridge, MA: Harvard University Press, 2006).

${ }^{16}$ Mail Obomsawin, "This Land is Whose Land? Indian Country and the Shortcomings of Settler Protest." Smithsonian Folkways June 14, 2019. https://folklife.si.edu/magazine/this-land-is-whoseland-indian-country-settler-protest.
} 
American male composers. ${ }^{17}$ Kajikawa notes how the reproductive technologies of US-based music schools limit the possibilities for music creation and interaction. Indeed, such an agnotological stance, a willful ignorance or active forgetting, closes off more just and equitable futures for Indigenous People in particular, but all peoples more broadly. ${ }^{18}$

In 2018 a coalition of graduate students and faculty members founded "Project Spectrum" with the goal of diversifying music studies (music theory, musicology, and ethnomusicology). ${ }^{19}$ However, at the time of this writing Native American and Indigenous scholars and students have yet to be fully included in these efforts. This erasure is reflected in the project's mission statement that situates marginalization in ways that excludes Indigeneity, which, to be clear, is not the same as race or ethnicity and is separate from "people of color." The BIPOC Project (Black, Indigenous, and People of Color) offers one example of how advancing social justice requires sustained engagement with the particularities of Native American and African American peoples' experiences with settler colonialism, "which shapes the experiences of and relationships to white supremacy for all people of color within a U.S. context." ${ }^{20}$

Following the work of Hayden White, Susan McClary critiques the insular, and one might argue extractivist, tendencies of music studies to "borrow ideas from historians all the time, but [then] rarely give anything in return." ${ }^{21}$ This volume's authors are actively engaged with the Indigenous communities featured in their work, and model the ways in which music studies can in fact give back by being in reciprocal relationships with Indigenous communities past, present, and future.

Another concrete action scholars can take revolves around deliberate citational practices that acknowledge and privilege the voices and perspectives of Indigenous authors, artists, and intellectuals. As Eve Tuck (Unangax) and K. Wayne Yang state in their call for critical citational practices: "our practices of citation make and remake our fields, making some forms of knowledge peripheral." ${ }^{\text {22 }}$ Writing about the speech acts institutions use to either commit (performative) or not (non-performative) to transformative diversity, Sara Ahmed reminds us that "a

${ }^{17}$ Loren Kajikawa, "The Possessive Investment in Classical Music: Confronting Legacies of White Supremacy in U.S. Schools and Departments of Music," in Seeing Race Again: Countering Colorblindness across the Disciplines, ed. Kimberlé Williams Crenshaw, Luke Charles Harris, Daniel Martinez HoSang, and George Lipsitz (Berkeley: University of California Press, 2019), 155-74.

${ }^{18}$ For a critique of white patriarchal privilege, power, and exclusion in United States-based musicology as a profession, see Tamara Levitz, "The Musicological Elite," in Current Musicology 102 (Spring 2018): 9-80.

${ }^{19}$ See Project Spectrum: a coalition of graduate students and faculty members committed to the issue of diversity in music theory, musicology, and ethnomusicology, https://projectspectrummusic. $\mathrm{com} / \mathrm{mission} /$.

${ }^{20}$ See The BIPOC Project: A Black, Indigenous, and People of Color Movement, https://www.thebipocproject.org/about-us.

${ }^{21}$ Susan McClary, "Feminine Endings at Twenty," TRANS: Revista Transcultural de Música 15, no. 5 (2011): https://www.sibetrans.com/trans/public/docs/trans_15_02_McClary.pdf.

${ }^{22}$ Eve Tuck and K. Wayne Yang, "Citation Practices." Accessed February 8, 2017. http://www.criticalethnicstudiesjournal.org/citation-practices/. 
performative acquires force only through citation and repetition." ${ }^{23}$ Racialization in music scholarship is obscured when whiteness or Western [European/American] voices are privileged as the only authorities. Simultaneously, as Ahmed reminds us, "The reproduction of a discipline can be the reproduction of these techniques of selection, ways of making certain bodies and thematics core to the discipline, and others not even part." 24 To institutionalize density in American music studies, we must think more critically about who we choose to cite and re-circulate in our work. If we do not, we risk the continued appropriation and/or erasure of Indigenous voices and perspectives.

\#4 "Recognizing Indigenous Identity"

"Indigenous style recognizes that Indigenous Peoples view themselves according to the following key principles:

- They are diverse, distinct cultures.

- They exist as part of an ongoing continuum through the generations tracing back to their ancient ancestors.

- They have not been assimilated into mainstream [settler] society, and their national and cultural paradigms have not been fundamentally altered or undermined through colonization.

- They are currently in a process of cultural reclamation and rejuvenation, marked by significant participation from Indigenous youth.

- Natural cultural change and adaptation do not mean that Indigenous people have acquiesced to mainstream [settler] society, nor that Indigenous cultures have been fundamentally altered or undermined."

Younging's fourth Indigenous style principle demands an attention to the density of Indigeneity: that writing and research with, by, and for Indigenous Peoples must account for the particularities of individuals and communities and avoid universalizing Indigenous Peoples as monolithic. The five essays collected here are diverse in their topics and methods, providing an array of approaches to the question of reframing American music studies in relation to Indigeneity and settler colonialism. Opening the issue, Kevin Fellezs (Kanaka Maoli) writes about the place of Indigenous aesthetics in understanding the relationship of slack key guitar music in the movement for Hawai'i sovereignty. In this article the key argument revolves around the concept of "nahenahe," or "sweetness," as it is translated into English. Fellezs interprets this key aesthetic for slack key music as capable of doing Indigenous political work that might not be visible or audible from a settler perspective. Trevor Reed (Hopi) likewise connects sound and sovereignty in the issue's

\footnotetext{
${ }^{23}$ Sara Ahmed, On Being Included: Racism and Diversity in Institutional Life (Durham: Duke Univ. Press, 2012), 126.

${ }^{24}$ Sara Ahmed, "Making Feminist Points," Feministkilljoys, 2013, accessed Accessed April 22, 2015, http://feministkilljoys.com/2013/09/11/making-feminist-points/.
} 
closing article by exploring the ways music can mediate Hopi political speech within a settler state in the US Southwest. Focusing on Hopi composition and performance of taatawi, or traditional songs, Reed argues that music in this context is political action.

Amanda Black and Karl Swinehart both extend the question of Indigenous-settler musical interactions into cases in Mexico and Bolivia, respectively, in which the contemporary international power of an imperial US plays out in relation to older Spanish settler colonial dynamics. In a socio-musical account of music-making in public space, Black explores the ways the economic power of largely-Anglo US retiree immigrants to the Mexican city of San Miguel de Allende has come to overdetermine racializations in relation to which local performers work. Also working with an ethnographic methodology, Swinehart looks at the ways blackness signifies for Aymara rappers in La Paz, Bolivia's hip-hop scene. Engaging the IndigenousAfrodiasporic-Settler triad theorized in settler colonial studies, Swinehart's work follows the effects of blackness not as a globally unified signifier, but rather as one that is itself subject to histories of conquest and distinguished by space and place.

Finally, Glenda Goodman's article offers a history of an aspect of Mohegan, Tunxi, Quinnipiac, Mattabeeset (or Wangunck) people's musical lives in the context of their interactions with English settlers in the area surrounding Farmington, Connecticut, in the late eighteenth century. This article confronts the question of how to do historical work that recognizes the presence of Indigenous music in earlier periods of American colonial settlement where documents are missing, and Indigenous voices have been silenced or suppressed in many archives.

In conclusion, we see this special issue as a beginning and as an invitation for more work, not a completed project. These five essays represent a field of possibility for a future of American music studies, and we look forward to reading more. We encourage readers to view these contributions as paths to a broader world of Indigenous research, and as a starting point for centering Indigeneity in research and pedagogy on music in the Americas. 